International Journal of Environment, Agriculture and Biotechnology
Vol-6, Issue-3; May-Jun, 2021

Article

Peer-Reviewed Journal

\title{
Profitability Assessment with the application of BRASS model of Small-scale Rubber Plantation at Chittagong Hill Tract, Bangladesh
}

\author{
A.K.M. Abul Kalam Azad ${ }^{13}$ Md. Najmus Sayadat Pitol ${ }^{2 *}$ and Yonosuke Hara ${ }^{3}$
}

\author{
${ }^{1}$ Bangladesh Planning Commission, Ministry of Planning, Agargoan, Dhaka \\ ${ }^{2}$ Bangladesh Forest Research Institute, Ministry of Environment, Forest and climate change, Bangladesh. \\ ${ }^{3}$ National Graduate Institute for Policy Studies (GRIPS), Tokyo, Japan. \\ *Corresponding author(s) e-mail: najmus.sayadat@gmail.com
}

Received: 21 Mar 2021; Received in revised form: 30 Apr 2021; Accepted: 21 May 2021; Available online: 07 Jun 2021

(C)2021 The Author(s). Published by Infogain Publication. This is an open access article under the CC BY license

(https://creativecommons.org/licenses/by/4.0/).

\begin{abstract}
This study concentrated on the profitability assessment of the small-scale rubber production by applying the Bioeconomic Rubber Agroforestry Support System (BRASS) model of Small-scale Rubber Production at Chittagong Hill Tract, Bangladesh. Considering the present market conditions of the cost of materials, land costs, labor costs, rubber prices and discount rate, the results of the Discounted Cash-flow (DCF) analysis indicate that the investment on small-scale rubber plantations in the Chittagong Hill Tracts is not profitable in the short run but in the long run, it is profitable. Rubber production is highly profitable if the government provides an interest-free loan to the poor farmers, and the farmers can reduce their investment costs. The farmers can control the investment costs by co-management. Rubber cultivation can be made more profitable if the farmers cultivate intercropping in their garden for the first few years. Considering the present market situation, the DCF analysis for the study shows that 28 years is the optimum rotation in small-scale rubber plantations with intercropping. With this optimum rotation, the CHT area can be financially most profitable for small-scale farmers. Investment in rubber plantations gives decent economic returns to the small-scale farmers. With the high discount rate, the investment in small-scale rubber plantations is no more profitable. Therefore, the government should allow interest-free credit or very low-interest rate credit support to small-scale rubber cultivators to make the maximum investment profit. With no intercropping, small-scale rubber cultivation is no more profitable. So, in line with the government policy of restricting shifting cultivations, the government should allow small-scale farmers to cultivate intercrops along with rubber cultivations.
\end{abstract}

Keywords-Discounted cash-flow (DCF), labor cost, net present value (NPV), rotation, value added tax $(\boldsymbol{V A T})$.

\section{INTRODUCTION}

In Bangladesh, the increasing demand for rubber and rubber products insisted on the new moneymaking plantation of rubber. Other hands, create any plantation near and within a natural forest or hill decreases the diversity of the forest (Rahaman et al. 2020). But still, rubber plantation proved as an excellent tool to cope with the food, wood, energy, ecology, poverty crises and lessen the deforestation rate of forest lands in Bangladesh. At present, both the governmental and private sectors 18,954 ha plantation of $H$. brasiliensis has been developed and planned to expand its further 1214 ha during 2020 (BFIDC, 2015; Hossain, 2016). The artificial plantations are storing a huge amount of carbon from the environment (Pitol et al. 2019) where rubber trees also acting a carbon soak with latex production (A.K.M Azad et al. 2021). Rubber cultivation is environmentally suitable compared to shifting cultivation. Some people also argue that rubber cultivation can help to 
eradicate poverty in the Chittagong Hill Tracts (CHT) in Bangladesh (Nath et al., 2013). For this reason, the government (then Pakistan) first introduced commercial rubber cultivation in 1961 engaging the forest department (BFIDC, 2013). 20 years later since the 1980s, the Bangladesh government took various programs and projects to promote rubber cultivation involving the local people. In 1985, with the help, ADB's financial support government took another project to enhance the involvement of local farmers in rubber cultivation (Nath et al., 2005). However, all these initiatives fail to achieve their expected goals (Rasul, 2005). Nonetheless, later the government took another policy decision to lease out fallow land to the farmers to cultivate rubber (BFIDC, 2012). To find out the reasons for previous government policy failure, this study concentrates on the profitability assessment of the smallscale rubber production by applying the Bioeconomic Rubber Agroforestry Support System (BRASS) model. This model is now widely used in other Asian countries like Indonesia and Lao PDR.

\section{MATERIALS AND METHODS}

\subsection{Study area}

Much more time and labors are required to carry out the detailed study of above issues because many small-scale rubber gardens were located in different regions that was impossible to complete the study. In this study, only one village named Rajbila was studied which is located at Bandarban upazila in Chittagong Hill Tracts (CHT) area. Rajbila village, is located in the Central Union (lower-level local government unit) at Bandarban Central (Sadar) Upazila in Bandarban District of Bangladesh. The total area of the village is 4.6 square kilometer where the small-scale rubber cultivation activities are going on. The total population of the Rajbila village is about 2570 with 492 households (BBS 2011).

\subsection{Data Collection and Analysis}

To find out the general overview of the small-scale rubber cultivators and shifting cultivators, both qualitative and quantitative data on rubber production, their income, resources, and other status were used. Data was collected by group discussion, direct observation, and a questionnaire survey of the households. There were 48 registered smallscale rubber cultivators and 38 shifting cultivators were interviewed. The focus group consultations were held with the village authorities to understand the general circumstances of the study area by information gathering on rubber and shifting cultivation. Lastly information regarding the quantity and cost of the labor force used for the rubber and shifting cultivation was collected. During the focus group discussion, several field observations were conducted with their cordial help.

\section{RESULT AND DISCUSSION}

\subsection{Undiscounted Cash Flow (UDCF)}

The estimated intercrop and latex production undiscounted cash flow of one-hectare rubber plantations from the year 131 years (Fig-1). Between 2-4 years, it was found that only intercrop revenue could be generated and hence, it showed positive. It was further found that the undiscounted net return of latex production was negative in the first year and 5-9 years. In the 10th year, it was started to positive flow and continue rising and become highest at the 20th year and again become declining slowly. At the age 16, it becomes less because some more extra cost was done due to fencing purposes. At the final 32nd-year timber harvesting cash flow is shown in Figure-4.

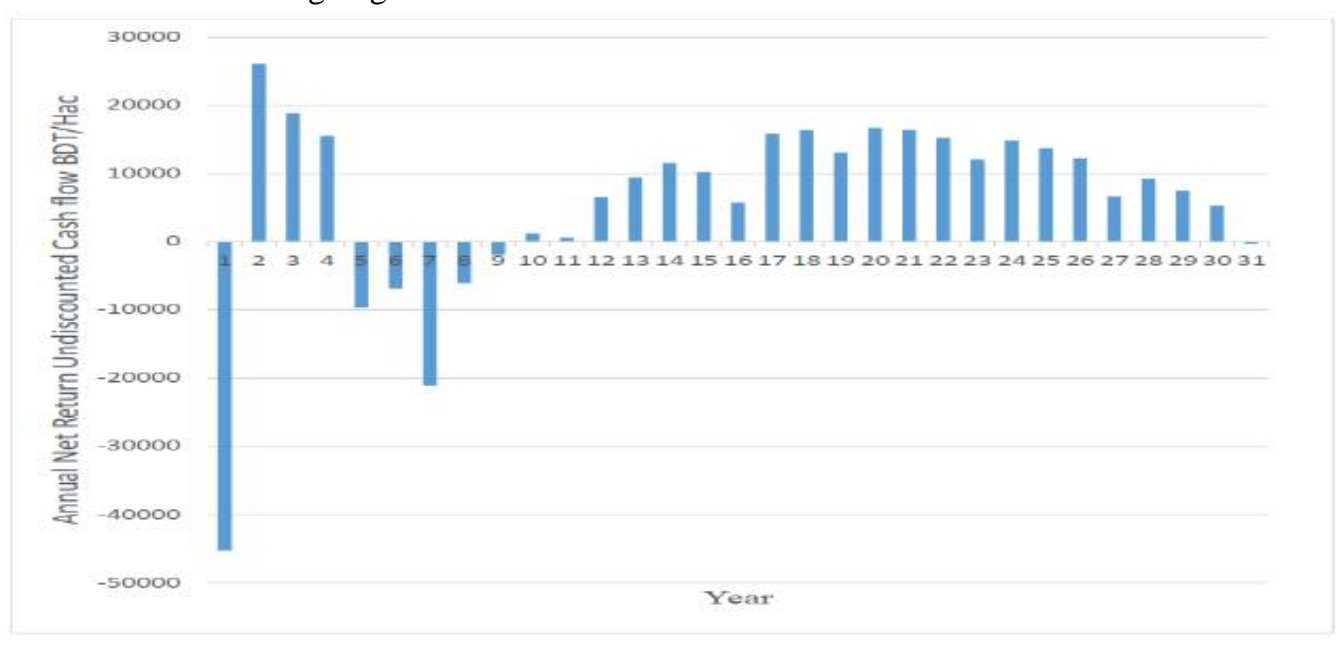

Fig.1: Undiscounted annual cash flow over 31 years lifetime 


\subsection{Discounted Cash Flow (DCF)}

All the costs and revenues are discounted at $8 \%$ and the estimated discounted net return of latex production during the year 7-31 was presented separately (fig-2). First two year after starting latex collection, discounted cash flow was negative. At the 10th year starting positive cash flow that was highest at the year $19^{\text {th }}$ and later on again decreasing the undiscounted cash flow because of decreasing the latex production. In the 17 th year, it shows less cash flow because some more management expenses like fencing were done in this year. From the $1^{\text {st }}$ to $6^{\text {th }}$ year, we have some discounted cash flow because 1-4 years we have some revenue from intercrop in the rubber plantations. There was also timber production in the final year of the production cycle that was presented in the next figure of cumulative NPV.

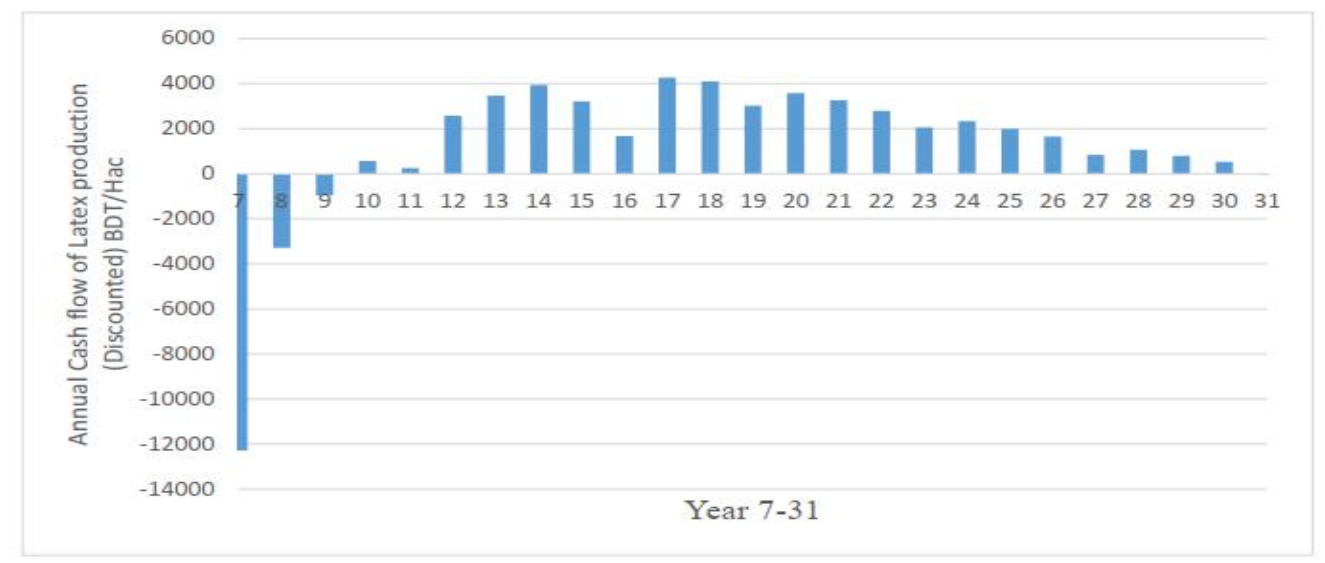

Fig.2: Discounted annual net cash flow of rubber (latex) production (7-31 years)

\subsection{Cumulative Net Present Value (NPV)}

The cumulative NPV becomes positive from the year 19th that reflects that it requires at least 19 years of planning horizon investment in rubber production to be profitable (Fig 3). In terms of applied three investments criteria, the
NPV of rubber production was 147735 BDT, the IRR was $15.67 \%$ that was above the discount rate at $8 \%$, and the BCR was 1.30. Therefore, the DCF analysis of small-scale rubber production shows that the cumulative NPV was negative up to the $18^{\text {th }}$ year and then it became positive and at the final year, it becomes highest because of timber harvesting.

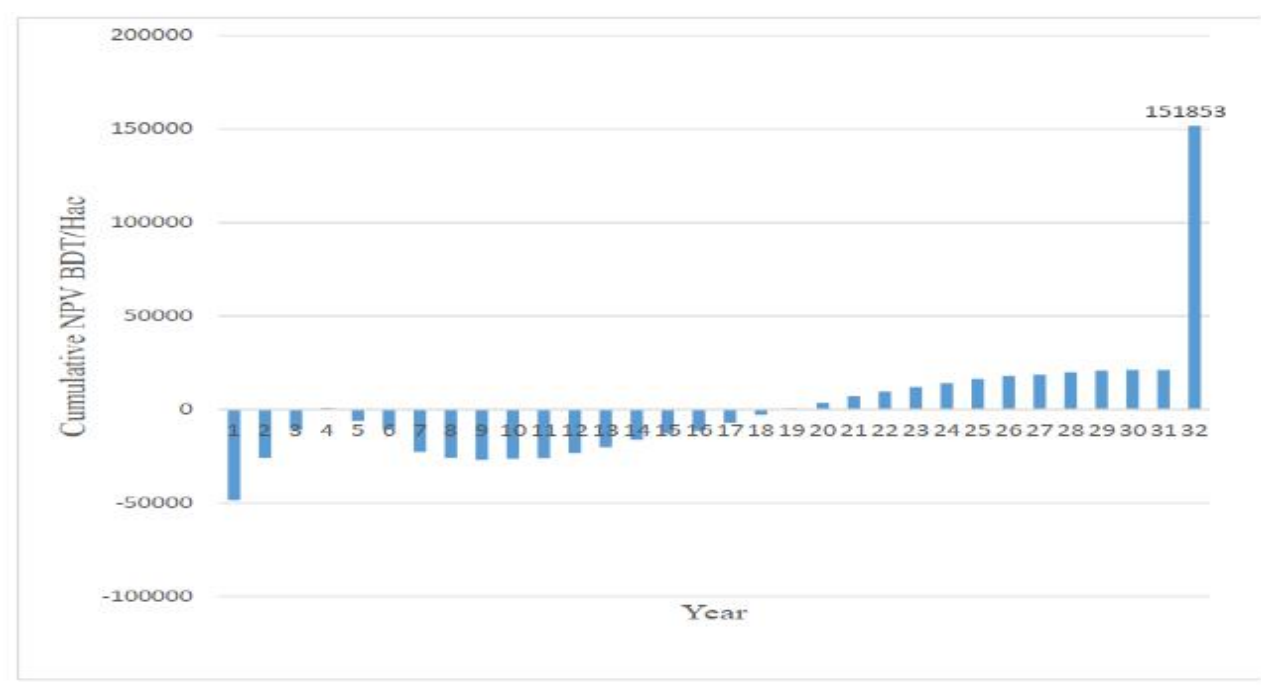

Fig.3: Cumulative NPV over 32 year's lifetime of rubber production

\subsection{Cumulative NPV Without Considering Unpaid Family Labor Costs}

The cumulative NPV becomes positive from the year 3rd and never goes beyond negative later on (Fig-4). The labor cost of unpaid family labor is estimated to be at the opportunity cost of family member because in CHT there exist the job opportunities for them. However, there are many areas of small-scale rubber production in Asia, where such job opportunities are not available (Manivong and 
Cramb, 2008 a b). Of course, in such cases, the small farmers can get revenue from selling latex. By taking into account this, cumulative NPV without considering unpaid family labor costs is estimated here. The total labor requirement for 32 years of rubber production is 4200 mandays (MDs) of which 2311 MDs (55\%) were from unpaid family labors, and 1889 MDs (45\%) were from hired labors. The wage rate of unpaid family labor cost was evaluated as zero and for the hired labor was calculated as the local wage rate $340 \mathrm{BDT} / \mathrm{man}$-day. The discount rate $(8 \%)$ and the rubber price (175 $\mathrm{BDT} / \mathrm{KG}$ ) was evaluated same as the base calculation. In this criterion the NPV of small-scale rubber production was $365756 \mathrm{BDT}$, the IRR was $36 \%$ that was much above the discount rate at $8 \%$, and the BCR was 2.33 . From the above DCF analysis of small-scale rubber production, it can be said that how to evaluate the opportunity cost and unpaid family labor cost is a very crucial issue in DCF analysis.

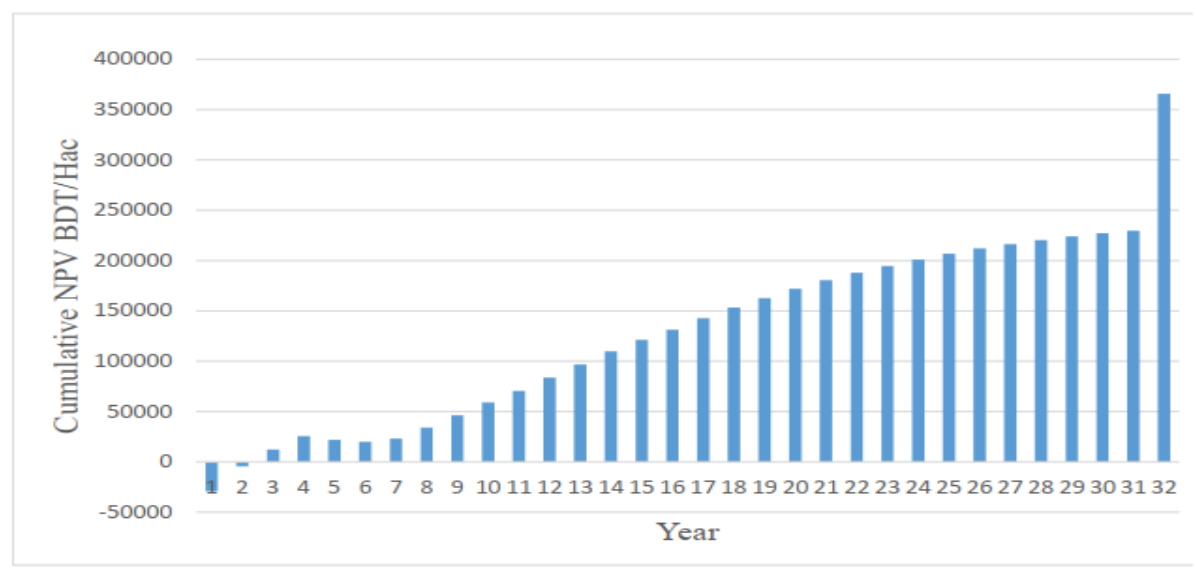

Fig.4: Cumulative NPV over 32 year's lifetime of rubber production without family labor cost

\subsection{Sensitivity Analysis}

The small-scale rubber cultivation is a long-term investment and may not assure the exact estimated NPV, IRR, and BCR. As the management strategies, different costs, prices, wages and rate of interests are subject to change over time, the probable result of these changes should be estimated (Gregory, 1987). There is no guarantee that the exact estimated NPV, BCR, and IRR will be obtained for the longtimeinvestment. In prediction, uncertainty may be involved in future, and it should be considered in the DCF analysis. There are various methods to incorporate uncertainty into the DCF analysis. The most common method is the sensitivity analysis. The main factors that may greatly affect the overall outcomes of small-scale rubber plantations in the Chittagong Hill Tracts are the management, material cost, labor cost, value added tax, wage rate of labor, the price of latex, and the discount rate by changing different controllable variables.

\subsubsection{Sensitivity Analysis of Different Controllable and Uncontrollable Variables}

All of the variables of the model associated with the smallscale rubber production can be divided into two groups such as controllable variables and uncontrollable variables. The variables on which there is no control by the government or the farmers is termed as uncontrollable variables. Examples of such uncontrollable variables are climate variables (rainfall, temperature, solar radiation, and potential evapotranspiration), and soil and topographic variables (slope of the land, soil texture, soil nutrients, soil moisture content, soil $\mathrm{pH}$ ). The variables on which the farmers or the government has the control to change are controllable variables, such as value added tax (VAT), rate of interest, rubber management (number of plants per unit area, types of species, co-management, fencing, fertilizing, tapping, harvesting), labor costs and material costs (reducing cost by co- management, preparation of land, quantity of materials used, reducing labor costs, family labor etc). The controllable variables are again divided into two groups such as government controllable variables and farmer's controllable variables. The variables that control depends on the decision of the government is government controllable variables such as VAT and interest rate. On the other hand, the variables that control depends on the farmers are called farmers controllable variables such as some variables of rubber. management, intercrop management, labor cost and material cost. The controllable variables play a significant role in profitability assessment and policy decision.

\subsubsection{Results of Changing Controllable Variables}

The analysis was done with DCF model application, changing some government controllable variables and farmers controllable variables and found relations between them. The differences of baseline calculation and changing government and farmers' controllable variables are as follows: The government controllable variables are value 
added tax (VAT) and an interest rate of the government bank. The farmers have to pay $15 \%$ VAT on the revenue of rubber products. If the government does not impose any VAT $(0 \%)$ on rubber products, then the NPV result may change. The baseline calculation, the discount rate was $8 \%$. For the government controllable variable analysis, it may be considered as $5 \%$. So, the main changes are VAT $(0 \%$ instead of $15 \%$ ) and discount rate (5\% instead of $8 \%$ ) separately in case of government controllable variables.

In the case of farmers controllable variable some labor costs and material costs are separately controlled and analyzed. In the baseline calculation, the rubber cultivation was evaluated as an individual. The major differences in this analysis were changing of some material costs and labor cost by applying co-management. In this case, several farmers (in this case 4 farmers) cultivate rubber plantations together and sharing some materials for raising their gardens. For the baseline analysis the total material cost for whole life cycle was 149560 BDT, but in this calculation, the total material cost was 132015 BDT that could save 17545 BDT for the whole life cycle of rubber plantations. The major portion of material costs reduces in the initial year of rubber plantation that is 3015 BDT. This cost reduces for sharing materials that are axe, knife, wire, posts, sharpening stone, handy saw, etc. Similarly, when the farmers cultivate the rubber plantations together, then they can also reduce some labor costs as well. The baseline total labor requirement for whole life cycle was 4200 man-days but, in this case, the total labor requirement for one unit of rubber garden is 3902 man-days that can save 298 man-days labor cost. The main activities which reduce the labor costs are land slashing, burning, cleaning, and fencing tapping and final tree harvesting. Itshows that if the government does not impose value added tax on rubber products or reduce the rate of interest and the farmers reduce some labor costs or reduce some material costthat is under their control. Then the result shows that the small-scale farmers achieve highest NPV (4,26,667 BDT) and BCR (1.65) among the four variables when the government reduces the rate of interest on the loan and farmers reduce some labor costs (Table-1). The second highest NPV $(3,83,882$ BDT) and BCR (1.55) receive when the government reduces the VAT, and the farmers reduce some labor costs. The lowest NPV $(2,48,828$ BDT) and BCR (1.52) come when the government does not impose VAT and farmers reduce some Table material costs (Table-1). The analysis also shows the result of combined control of farmer's and government controllable variables. In this case, if the farmers control the labor and material cost together then the highest NPV (4,32,402 BDT) and BCR (1.67) achieved when the government reduces the interest rate. On the other hand, if the government do not impose any VAT and reduces interest rate then the highest NPV $(5,94,873 \mathrm{BDT})$ and BCR (1.91) receives when the farmers can reduce some labor costs. The best NPV $(6,00,609$ BDT) and BCR (1.93) can be achieved when farmers can control both labor costs and materials costs, and government reduces the interest rate and VAT on products (Table-1). If the farmers do not pay VAT, then it will also be profitable on base discount rate. The farmers can reduce the labor costs and material costs by doing co-management for small-scale rubber farming. So, from the result, it can be summarized that interest rate is the most crucial variable for the smallscale rubber cultivators to obtain maximum benefits from rubber cultivation.

Table-1: NPV and BCR relation between government and farmers-controlled variables

Farmer's controllable variables

\begin{tabular}{|c|c|c|c|c|}
\hline & & Labor & Material & Labor and material \\
\hline \multirow{6}{*}{ 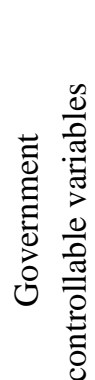 } & VAT & 279515 & 248828 & 284272 \\
\hline & & $(1.62)$ & $(1.52)$ & (1.64) \\
\hline & & 426667 & 383882 & 432402 \\
\hline & Interest rate & $(1.65)$ & $(1.55)$ & $(1.67)$ \\
\hline & & 594873 & 552089 & 600609 \\
\hline & VAT and interest rate & $(1.91)$ & $(1.79)$ & $(1.93)$ \\
\hline
\end{tabular}

\subsubsection{Sensitivity Analysis of Changing of Price, Wage Rate and Discount Rate}

As prices, wages and rate of interests are subject to change over time, the probable result of these changes should be estimated. The baseline calculation presented the DCF analysis of a typical one-hectare small-scale rubber production at $8 \%$ discount rate, 334 BDT per man-day of wage rate and the current local market price of rubber 175 $\mathrm{BDT} / \mathrm{KG}$. The main factors that may greatly affect the overall outcomes of small-scale rubber plantations in the 
Chittagong Hill Tracts are the wage rate of labor, the price of latex, and the discount rate. The highest wage rate was 500 BDT per man-day, and the present discount rate was $8 \%$. The present market price of latex was $175 \mathrm{BDT} / \mathrm{Kg}$. Last five years lowest price of the latex was $150 \mathrm{BDT} / \mathrm{KG}$ and the highest price was $200 \mathrm{BDT} / \mathrm{KG}$. So, the lowest and the highest price of latex was assumed as $150 \mathrm{BDT} / \mathrm{KG}$ and 200 $\mathrm{BDT} / \mathrm{KG}$ for the sensitivity analysis. At the same time highest discount rate was assumed as $17 \%$ because some private bank allocate loan at higher interest rate. The lower discount rate was assumed as around 35\% lower than the present discount rate. The sensitivity analysis was conducted in two different wage rates. The basic wage rate was 334 BDT per man- day, and the highest wage rate was 500 BDT per man-day. The results are presented separately in two different tables. Table-2, shows the sensitivity analysis at three different market prices of latex and three different discount rates with present wage rate. The three different prices are $150 \mathrm{BDT} / \mathrm{Kg}, 175 \mathrm{BDT} / \mathrm{Kg}$ and $200 \mathrm{BDT} / \mathrm{Kg}$. The three different discount rates are $5 \%, 8 \%$ and $17 \%$ with the base wage rate $334 \mathrm{BDT} /$ day (Table-2). The result shows that rubber production investments are profitable on $5 \%$ and $8 \%$ discount rates. The result also demonstrates that the investment is profitable ( $\mathrm{NPV}=10075, \mathrm{BCR}=1.04$, and IRR $=18.78)$ at the high-level of the discount rate $(17 \%)$ if the rubber price is higher (200 BDT/Kg) (Table-2). Conversely, if there is no change of rubber price (baseline rubber price at $175 \mathrm{BDT} / \mathrm{Kg}$ ) but the discount rate is increased up to $17 \%$, the investment on small-scale rubber production will be at a loss. The investment on small-scale rubber plantations cann ot be profitable in this case because, the BCR is less than 1 (0.97), and IRR is $15.74 \%$ that is less than $17 \%$. Perhaps this situation could be managed by increasing the latex yields (by using fertilizer) and by reducing the labor costs and material costs as far as possible.

Table 2: Sensitivity (DCF) analysis on the basis of wage rate 334 BDT/MD

\begin{tabular}{|c|c|c|c|c|}
\hline \multirow{3}{*}{$\begin{array}{l}\text { Price of } \\
\text { Rubber } \\
\text { BDT/KG }\end{array}$} & \multicolumn{3}{|c|}{ NPV (BDT/Ha) and B/C at different discount rates } & \multirow{2}{*}{ IRR } \\
\hline & $5 \%$ & $8 \%$ & $17 \%$ & \\
\hline & & & & \\
\hline \multirow[t]{2}{*}{150} & 289473 & 97231 & $(-23868)$ & 12.67 \\
\hline & 1.41 & 1.20 & 0.90 & \\
\hline \multirow[t]{2}{*}{175} & 377126 & 151853 & $(-6897)$ & 15.74 \\
\hline & 1.54 & 1.31 & 0.97 & \\
\hline \multirow[t]{2}{*}{200} & 464780 & 206475 & 10075 & 18.78 \\
\hline & 1.66 & 1.42 & 1.04 & \\
\hline
\end{tabular}

It also found that, the result of sensitivity analysis for highest wage rates (500 BDT/man- day) using three discount rates $(5 \%, 8 \%$ and $17 \%)$ and three latex prices $(150$ $\mathrm{BDT} / \mathrm{KG}, 175 \mathrm{BDT} / \mathrm{KG}$ and $200 \mathrm{BDT} / \mathrm{KG}$ ) for a typical one-hectare rubber production (Table-3). This analysis revealed that the small-scale rubber production is not profitable at all three kinds of latex prices at the baseline discount rate $(8 \%)$ and higher discount rate $(17 \%)$. The small-scale rubber production is only profitable at the lower discount rate $(5 \%)$ at baseline prices of latex (175 BDT/KG) and increased price of latex (200 BDT/KG) (Table-3). So, small- scale rubber production is not profitable at all kinds of discount rates when the price of latex is low. It is also unprofitable at baseline and increased discount rates at all prices of latex. In this situation, the farmers should stop the tapping activities temporary or trying to reduce management costs and labor costs by using family labors. Co-management may be very helpful to reduce the labor costs and management costs. So, when wage rate and interest rate increase together, then the investment on smallscale rubber plantation is not viable. In this case, the government should offer subsidies to the farmers and take action to reduce the interest rate.

Table-3: Sensitivity (DCF) analysis on the basis of higher wage rate 500 BDT/Man-day

\begin{tabular}{|c|c|c|c|c|}
\hline \multirow{2}{*}{$\begin{array}{l}\text { Price of Rubber } \\
\text { BDT/KG }\end{array}$} & \multicolumn{2}{|c|}{ NPV (BDT/Ha) and B/C at different discount rates } & \multirow{2}{*}{ IRR } \\
\cline { 2 - 5 } & $5 \%$ & $8 \%$ & $17 \%$ & 4.73 \\
& $(-15896)$ & $(-110970)$ & 0.64 & \\
\cline { 2 - 5 } & 0.98 & 0.84 & $(-118593)$ & 6.28 \\
\hline
\end{tabular}




\begin{tabular}{|l|c|c|c|c|}
\hline \multirow{2}{*}{200} & 1.07 & 0.91 & 0.69 & \\
\hline & 159942 & $(-1510)$ & $(-84634)$ & \multirow{2}{*}{7.95} \\
\cline { 2 - 4 } & 1.16 & 0.998 & 0.74 & \\
\hline
\end{tabular}

\subsection{Optimum Rotation Calculation}

The government of Bangladesh is allocating fallow land in hill districts for rubber cultivation to reduce shifting cultivation due to soil erosion. The government has already established a rubber standing committee to excel the program of establishing private rubber cultivations. Under this scheme, a total 3915.40-hectare khash land (fallow land) were distributed in Bandarban Hill District for 40-50 years lease (Khisa, 1991). The government allowed 5 years to start rubber plantation after handover the lease of land to the farmers. Though 32 years are considered to be normally for the rubber cultivation, there is no study to show that the optimum rotation of rubber production in Bangladesh. Some cases it was found that the farmers do not start plantation in time just after getting the lease of land. Some farmers use the land for other purposes instead of rubber cultivation such as ginger cultivation, garlic cultivation as they got few years facility to start rubber cultivation which do not fulfill the main objective of government policy to reduce shifting cultivation and soil erosion (Rasul, 2005). Sometimes, farmers require more than 32 years because they cannot start plantation just after allocation of land. In this situation, it is very necessary to find a solution how can solve this misuse of leased land. Hence, tried to find out the optimum rotation of rubber plantation to minimize the land lease period and maximize the land use. Some cases farmer's rubber plantations are uneven, and they cannot harvest the timber at the same times. Here in this study, considered that all of the rubber seedlings plant in the same year of a particular garden, and it became all the trees are the same age, so the farmer can harvest all the timber at the same time. Different farmers have a different year of plantation.
The land allocation and rubber plantations may not be the same time for all farmers. In this section, an optimum rotation for small-scale rubber plantations is estimated based on the revenue that is generated from the latex and wood price. From the BRASS model, total life cycle latex and wood production were calculated to find the net present value (NPV) which was combined to estimate the optimum rotation for rubber plantations in the study area. Wood prices are combined with annual cash flow to calculate the optimum rotation that maximizes the net present value for the rubber farmers. The NPV of rubber production with intercropping and without intercropping are calculated at different possible rotation cycle in the yield table to find out the optimum rotation at which the NPV is maximized.

\subsubsection{NPV of Small-scale Rubber Cultivation with Intercrop Production}

The small-scale rubber plantations with intercrop become positive NPV at the plantation age of 13 years (Fig-5). The NPV becomes positives over the 13 years due to wood products that become mature to harvest at this age. It is clearly found that at 33 years of the production period, the NPV increases from the 13 years highest (178193 BDT) at the 28th year (Fig-5). After that, its NPV value decreases. Therefore, 28 is the optimum rotation of rubber cultivation of small-scale rubber cultivation with intercropping to derive optimum benefit from the study area under the present conditions. Presently, Bangladesh is following 32 years of rotation of rubber plantations. According to this result, the rotation can be reduced by four more years to yield the optimum profit from the rubber cultivations if intercrops are cultivated along with rubber plantations for early three or four years.

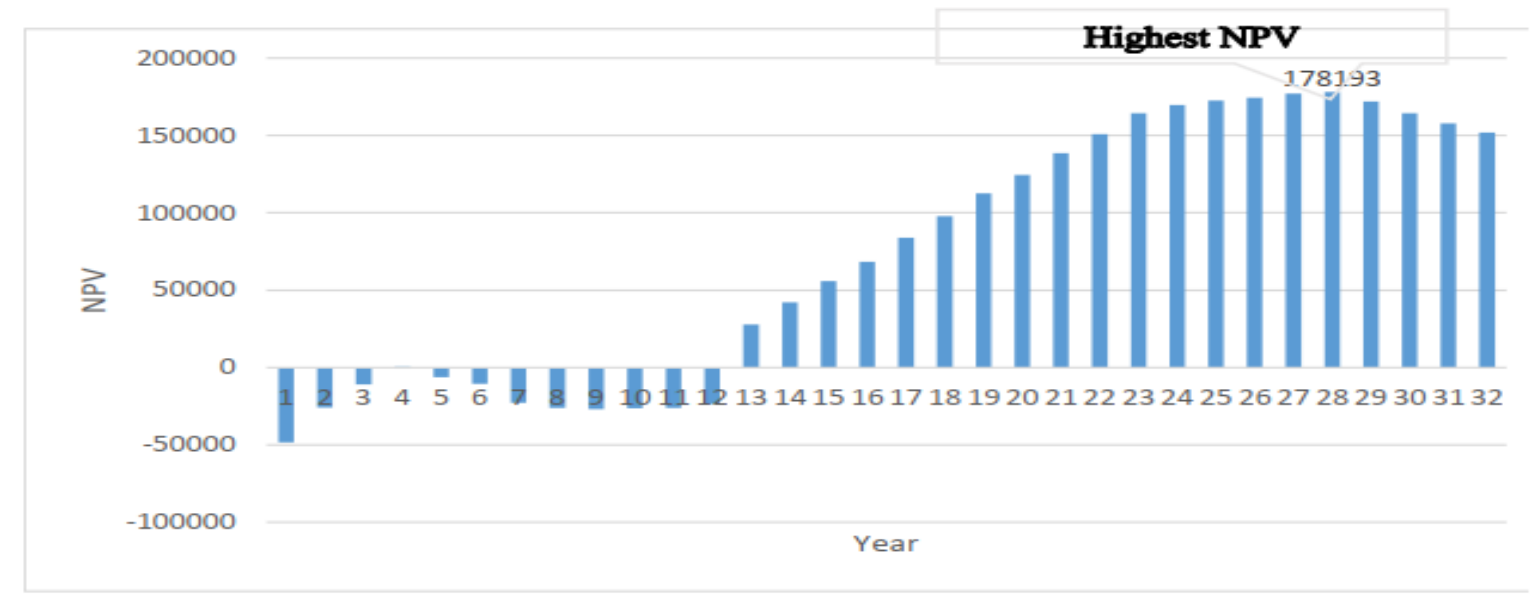

Fig.5: Cumulative NPV up to 32 years rubber production with intercrop production 


\subsubsection{NPV of Small-scale Rubber Cultivation Without Intercrop Production}

The result shows that without intercrops in rubber farm, the NPV of small-scale rubber production is negative up to 17 th years (Fig-6). At the 18th year, the NPV (6790 BDT) become positive and increase up to 28 th year (87197 BDT).
This result indicates that there should be a minimum of 28 years to increase the NPV value (Fig-6). It is clear that without intercrop production in the rubber garden in the initial 17 years, there is no profitability. It also shows that the optimum rotation is 28 years with highest NPV for rubber cultivation without intercropping. Thus, the rotation should be 28 years to get maximum profit.

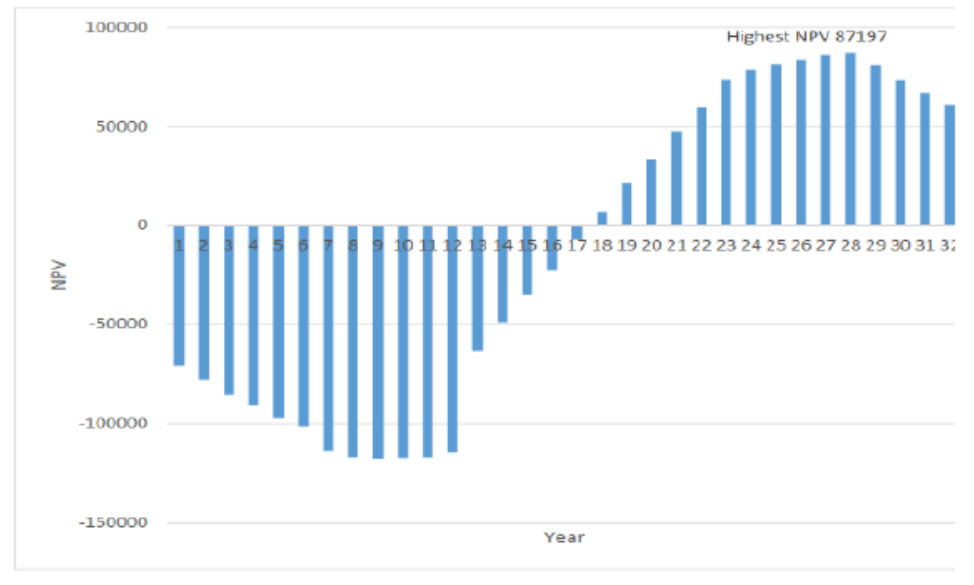

Fig.6: 32 years Cumulative NPV of rubber production without intercrop

3.6.3 Comparison of NPV with and without intercropping when there is no VAT

The small-scale rubber cultivation with intercropping is more profitable system than rubber monoculture or small- scale rubber cultivation without intercropping under the current market conditions (Fig-7). The order does not depend on age since there is no cross point of the NPVs of the two small-scale rubber production system.

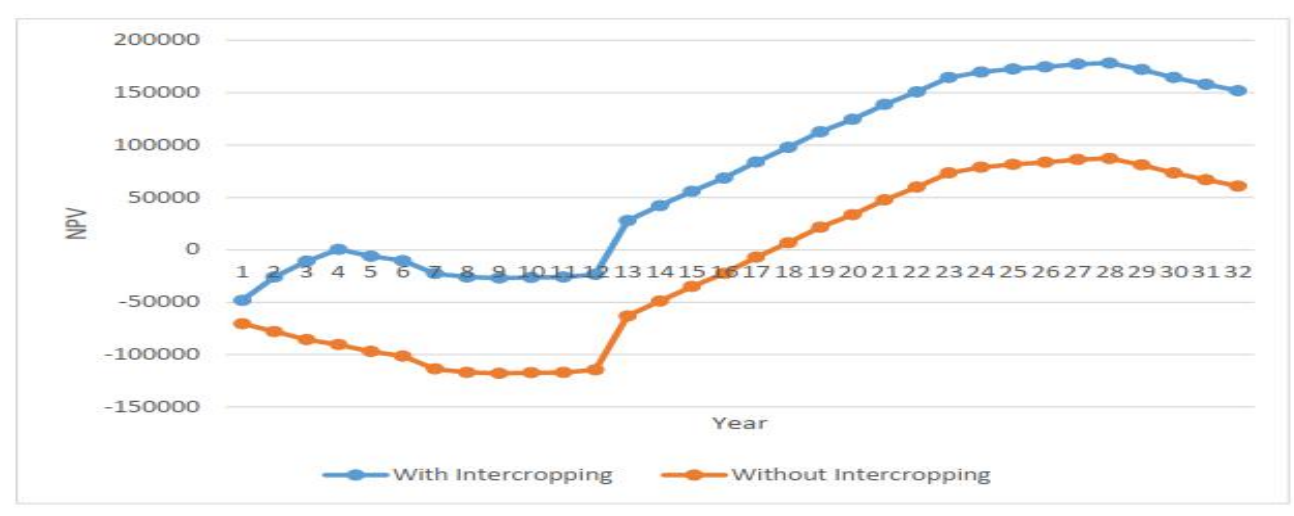

Fig.7: Comparison of NPV with intercropping and without the intercropping

\subsubsection{Comparison of NPV with and without Intercropping in the case of VAT and no VAT}

The optimum rotation with intercrop is 28 years if there is VAT or no VAT. Similarly, optimum rotation without intercrop is 28 years if the farmers pay VAT or no VAT (Fig-8). The result reflects that VAT has no effect on optimum rotation, but it has a significant impact on profitability or NPV. If the farmers do not pay VAT, they achieve maximum output, but they achieve minimum output in case of paying VAT. The difference of NPV varies significantly between intercropping and no- intercropping because intercrop productions do not need to pay any VAT for the farmers. 


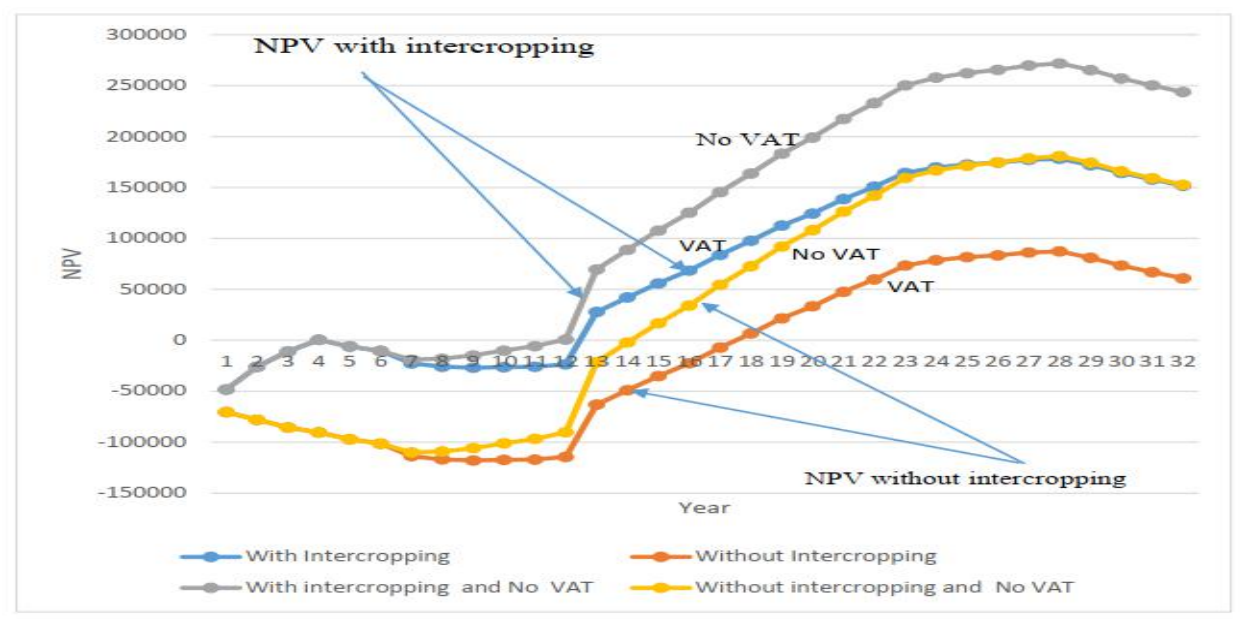

Fig.8: Comparison of NPV with and without intercropping considering VAT and no VAT on latex

\subsection{Sensitivity Analysis of Optimum Rotation}

Since rubber cultivation is a long-time investment, hence there is no assurance on the exact estimated NPV and optimal rotation will be obtained. Since intercrop cultivation, rubber prices and rate of interests are subject to change over time, the probable result of these changes should be estimated (Gregory, 1987). Therefore, sensitivity analysis plays a significant role in systematically testing how the NPV and rotation or life cycle would change when actual events in the future should differ from the present. In the study area, got the result using a base discount rate $8 \%$, wage rate $334 \mathrm{BDT}$ and latex price $175 \mathrm{BDT} / \mathrm{Kg}$. The main factors affecting the outcome of the production of the smallscale farmers are the price of latex and discount rate. In the study area, the lowest and highest price of $150 \mathrm{BDT} / \mathrm{Kg}$ and $200 \mathrm{BDT} / \mathrm{Kg}$, which is around $20 \%$ below and above the present market price (Table 4). The lowest discount rate of
$5 \%$ and highest discount rate of $17 \%$ are considered for the sensitivity analysis. The result of sensitivity analysis on small-scale rubber cultivation without intercropping as shown in Table-4, that with all base, lowest, and highest price of latex, the optimum rotation age is 28 years on both $5 \%$ and $8 \%$ of discount rate and any rubber price. From the both sensitivity analysis of small-scale rubber cultivation with and without intercropping, it was found that discount rate and rubber price are crucial to increasing the NPV and get more profit. Intercropping practice does not have any effect on optimum rotation. The optimum rotation can be 28 years in all cases of rubber prices with the base (present) and lower discount rate. On the contrary, if the discount rate increased then the farmer should stop to invest in rubber cultivation. Thus, if the government plans to produce rubber and to eradicate shifting cultivation, the small-scale farmers should be given low-interest rate loan and subsidies to invest in this sector.

Table 4: Optimum rotation and NPV of rubber production without intercropping

\begin{tabular}{c|c|c|c|}
\hline \multirow{2}{*}{$\begin{array}{l}\text { Price of Rubber } \\
\text { BDT/KG }\end{array}$} & \multicolumn{3}{|c|}{ Optimum Rotation and NPV at different discount rates } \\
\cline { 2 - 4 } & $5 \%$ & $8 \%$ & $17 \%$ \\
\hline \multirow{2}{*}{150} & $28 \mathrm{Yr}$ & $28 \mathrm{Yr}$ & $\infty$ \\
& 222225 & 35228 & $(-84306)$ \\
\hline \multirow{2}{*}{175} & $28 \mathrm{Yr}$ & $28 \mathrm{Yr}$ & $\infty$ \\
& 302930 & 87197 & $(-68359)$ \\
\hline \multirow{2}{*}{200} & $28 \mathrm{Yr}$ & $28 \mathrm{Yr}$ & $\infty$ \\
& 383636 & 138866 & $(-52413)$ \\
\hline
\end{tabular}

\section{LIMITATION AND FUTURE STUDY}

Some limitations must be pointed out. The data was collected from one village. Further study needs to be done not only to include other villages and locations but also with 
different types of intercropping cultivation. Another important fact that needs to be considered but not addressed is the environmental benefit. The environmental benefit is much broader than the soil property, how to combine other environmental services to create an integrated ranking is another technical challenge. Many other methodologies could be applied to assess the ecological and economic benefits of small-scale rubber cultivation.

\section{CONCLUSION}

The modification or extension of the BRASS model can be more applicable for formulating the rubber policy, not only in CHT but also in other areas of Bangladesh and other Asian countries. More importantly, the proper land use with rubber cultivation will change the livelihood of the tribal people. To allocate fallow land to the small farmers, the land lease period should be considered which is also crucial for the farmers as well as the government. Intercropping is another important element for the small-scale farmers to get someinitial benefits when there is no return from latex. The small-scale rubber cultivation could be a profitable investment in the long term and the optimum rotation is 28 years which generate an alternative livelihood for the shifting cultivators. The government controllable rate of interest on a bank loan and value added tax (VAT) and farmer's controllable labor costs and material costs are the most crucial variables that make the rubber cultivation more profitable. The government can assist the farmer by providing low-interest rate credit support or in some cases interest- free financial credit. So, if the government wants to reduce shifting cultivation, must come forward with a low-interest funding for the rubber cultivators.

\section{ACKNOWLEDGEMENT}

Authors thank to GRIPS, Tokyo, Japan. Also thank to the staff of Bangladesh Cotton Development Board, Bandarban, Bangladesh for aiding during data collection.

\section{REFERENCES}

[1] A.K.M. Abul Kalam Azad, Md. Najmus Sayadat Pitol and Yonosuke Hara. "The role of Rubber (Hevea brasiliensis) plantation in carbon storage at Bandarbans Hill Tract, Bangladesh", 2021. International Journal of Current Research, 13, (05), 17373-17377. DOI: https://doi.org/10.24941/ijcr.41365.05.2021

[2] Bangladesh Forest Industries Development Corporation (BFIDC). (2012). Ministry of Environment and Forest. Dhaka: Government of the People's Republic of Bangladesh.

[3] BBS. (2011). Bangladesh Census. Dhaka: Bangladesh Bareu of Statistics, Government of the Peoples Republic of
Bangladesh.

[4] BFIDC. (2013). Establishment of rubberwood treatment plant in project. Dhaka, Bangladesh: Ministry of Environment and Forest, Government of the Peoples Republic of Bangladesh.

[5] BFIDC. (2013). Rubber Statistics. Dhaka: Bangladesh Forest Industries Development Corporation.

[6] BFIDC. 2015. Garden and Industries, Bangladesh Forest Industries Development Corporation. (BFIDC) Government of the People's Republic of Bangladesh. http://www.bfidc.gov.bd/site/page/fa44e577-8362-4cbdac31-b0fd58445537/-Accessed on 26 December 2019.

[7] Gregory, G. R. (1987). Resource economics for foresters. New Jersey, USA: John Wiley and Sons Inc.

[8] Hossain MK. 2016. Plantation forestry- paradign to meet the demand of the forestry resources in Bangladesh. In: Monoculture Farming- Global Perspectives, Ecological Impact and Benefits/Drawbacks (T.K. Nath and Patrick O'Reily, Eds.), New York, Nova Publishers. Edition: 1st, Chapter: 3.

[9] Khisa, S. K. (1991). Parbatto Chattogram Hevea rubber chash abong prokriyajatkoron (in Bengali) (Chittagong Hill Tracts Hevea rubber cultivation and processing) (Vol. 336). Chittagong: Simanta Press.

[10] Manivong, V., \& Cramb, R. (2008b). The adoption of smallholder rubber production by shifting cultivators in Northern Laos: A village case study. Advances in Agroforestry, 5, 117-137.

[11] Manivong, V., \& Cramb, R. A. (2008a). Economics of smallholder rubber production in Northern Laos. Agroforestry System, 74(2), 113-125.

[12] Nath, T. K., Inou, M. \& Mangala, D. Z. (2013). Small-scale rubber planting for enhancement of people's livelihoods: A comparative study in three South Asian countries, society \& natural resources. An International Journal, 26(9), 10661081.

[13] Nath, T. K., Inoue, M., \& Myant, H. (2005). Small-scale agroforestry for upland community development: a case study from Chittagong Hill Tracts, Bangladesh. J For Res, 10, 443-452.

[14] Pitol MN, Khan MZ, Khatun R. 2019. Assessment of Total Carbon Stock in Swietenia macrophylla Woodlot at Jhenaidah District in Bangladesh. Asian Journal of Research in Agriculture and Forestry, 2(3), 1-10. https://doi.org/10.9734/AJRAF/2018/46922

[15] Rahaman, M. T., Gurung, D. B., \& Pitol, M. N. S. (2020). Comparative Study of Understory Between Exotic Monoculture Plantation (Acacia Sp.) and Adjacent Natural Sal (Shorea Robusta) Forest. European Journal of Agriculture and Food Sciences, 2(6). DOI: https://doi.org/10.24018/ejfood.2020.2.6.204

[16] Rasul, G. (2005). State policies and land use in the Chittagong Hill Tracts of Bangladesh. International Institute for Environment and Development. Gatekeeper series (119), 112-120. 